\title{
RESTRUCTURING THE ROMANIAN WOOD PROCESSING INDUSTRY
}

\section{Restruktuiranje rumunjske industrije obrade drveta}

\author{
Florin Ioras ${ }^{1}$, David Turnock ${ }^{2} \&$ Ioan Abrudan ${ }^{3}$
}

\begin{abstract}
Izvod
Ovaj rad predstavlja pregled restruktuiranja jedne od rumunjskih bazičnih industrijskih grana koja je doživjela značajne promjene od 1989. godine na ovamo, u smislu privatiziranja i izgradnje novih kapaciteta. Iako se proizvodnja nije vratila na nivoe iz perioda 1980-tih, desila su se kapitalna kvalitativna poboljšanja zahvaljujući u velikoj mjeri stranim ulaganjima, sa spektrom novih projekata koji su u tijeku. Dok će osnovni proizvodi najvjerojatnije doživjeti daljnja poboljšanja kroz proizvodnju, uz poštivanje viših ciljeva (nakon značajnog slabljenja u ranim 1990-im), napredak u planiranju proizvoda od drveta izgleda manje siguran, - osim vlaknih ploča srednje gustoće (medium-density fibreboard) (MDF) i iverice (particleboard or chipboard) (PAL - prema rumunjskoj skraćenici) - iako bi povećana potrošnja na domaćem tržištu mogla osigurati poticaj. U međuvremenu, visoke konkurentske cijene u industriji papira pomažu da se proizvodnja održi donekle iza potrošnje, osobito u slučaju novinskoga papira. S druge strane, kvalitetan dizajn i visoka radna produktivnost u nekim oblastima industrije namještaja pomažu održavanje dobrog izvoznog trenda, uz privlačenje investicija globalnih proizvođača kakav je IKEA.
\end{abstract}

Ključne riječi: privatizacija, normativi, ekonomski razvoj, Istočna Evropa, direktna strana ulaganja.

\footnotetext{
Abstract

The paper provides a summary of restructuring in one of Romania's basic industries that has seen major changes since 1989 on account of privatisation and the construction of new capacity. Although production has not returned to the levels of the 1980s there has been a major qualitative improvement thanks largely to foreign investment, with of new

${ }^{1}$ Buckinghamshire Chilterns University College, High Wycombe, Bucks HP11 2JZ

${ }^{2}$ Geography Department, University of Leicester, Leicester LE1 7RH, U.K

${ }^{3}$ Facultatea de Silvicultura si Exploatari Forestiere, Universitatea Transilvania, Sirul Beethoven No1, Braov, Romania
} 
projects currently underway. While the basic commodities are likely to see further recovery in output, in sympathy with greater felling (after a significant relaxation in the early 1990s), progress of engineered wood products - beyond medium-density fibreboard (MDF) and particleboard or chipboard (PAL - according to the Romanian acronym) seems less assured, though increasing domestic consumption could provide an incentive. Meanwhile stiff price competition in the paper industry helps to keep production some way behind consumption especially in the case of newspaper. On the other hand, good design and high labour productivity in some sections of the furniture industry is helping to maintain a good export performance while attracting investment from global producers such as Ikea.

Key words: privatisation, regulation, economic development, Eastern Europe, foreign direct investment.

\section{INTRODUCTION - Uvod}

This paper deals with a traditional Romanian industry given the wealth of raw material and its use since time immemorial for housing, equipment and fuel long before the development of factory industry. After the first large steam-powered sawmills appeared the late nineteenth century, along with factory-scale production for cellulose, paper and furniture (coexisting with smaller units typically operating at the scale of peasant family businesses using water power) the communist era added a network of regional combines taking total processing capacity to some $17 \mathrm{mln}$.cu.m with a varied profile including fibreboard and chipboard added to the more established products. However the industry was hardly capital-intensive and paid insufficient attention to maximising value-added. These are current challenges to be added to task of restructuring the inherited capacity on the basis of efficient private enterprise to meet the domestic market demand for building components, wood panels and furniture and exploit the competitive position of most Romanian furniture in foreign markets arising through domestic raw materials, skilled personnel and good export opportunities in Western Europe as well as the former Soviet bloc and the Middle East.

After the early transition years (1990-4) when production fell in all industrial branches, production has generally increased to meet new market demand (ISTRATESCU ET AL. 2001). Since central planning focused on large quantities of low quality output, privatisation has been widely accompanied by new technologies to overcome the 'gap' of some two decades characterised by low value-added and inadequate finance and market information. Restructuring of manufacturing began quite soon after the revolution of 1989, ahead of logging and transport. There has been a steady relative improvement for the wood processing, paper and furniture sectors, which accounted for $6.5 \%$ of total value-added in industry as a whole in $1990-2$, but $6.9 \%$ in $1993-5,7.4 \% 1996-8$ and $8.7 \%$ in 1999-2002. Trends within the sector have remained fairly stable with wood processing up slightly (36.3-37.4\%) and likewise furniture (plus 'other branches') (44.9-46.1\%) while paper has lost ground (18.8-16.5\%). However wood processing has shown some 
stability in employment after falling below 70,000 in 1996-7 it has averaged 74,000 during 1999-2003 while furniture has stabilised during this same period with an average of 100,000 and cellulose and paper on 17,000 (though still edging downwards). However as a result of the division of state asset and the creation of many new companies, Ministry of Industry ministry figures show that, compared with just 244 companies in the total wood industry in 1990 (107 in wood processing, 114 in furniture and other finished products and 23 in pulp and paper), there were 8,634 in 2002 (5,235 in wood processing, 2,965 in furniture and 434 in pulp and paper): $78.5 \%$ are SMEs with less than 500 employees. An Association of Romanian Foresters includes the great majority of the logging, transport and primary processing operators (with separate associations for the pulp-paper and furniture sectors.

As regards individual products, sawn timber declined sharply from the high average figure of $4.16 \mathrm{mln} . s q . m$ during the later communist years (1985-9) to a low of 1.51 in 1999-2000, but recovered to 2.99 in 2004 (Table 1). Other products show a roughly similar pattern but with varying degrees of recovery, with the best performance evident in fibreboard with an average of 262,000t for 1985-9 falling to 48,500 in 1998-9 and recovering to 280,000: higher than the average for the later communist years and also higher than any individual year during this period. On the other hand plywood fell from $206,000 t$ in 1985-9 to 71,000 in 1998-2000 and recovered to only 117,000 in 2004; while aesthetic veneer sheets amounted to only 31,000sq.m in 2002-4 after the 91,000 sq.m figure for 1985-9 collapsed to 22,000 in 1998-2000. For paper the 2004 figure of $492,000 \mathrm{t}$ is virtually identical to the 1985-9 average of 494,000t after lows of 248,000 in 1993 and 276,000 in 1999; yet paper for newsprint averaged 75,000 during 1985-9 and bottomed out at 31,000 in 1996 before recovering to only 55,000 during 2000-1 and falling back to 43,000 during 2002-4 due to uncertainty over ownership at the Letea factory in Bacău. In two cases comparisons with the late communist period are not possible but pulp and semi-pulp production during 2002-4 was higher than any other transition year apart from 1990; while chipboard production of 14,400t in 2004 shows a recovery from the average of only 9,200 during 1998-2002 but is still well below the average of 17,300 for 1993-7. As for the future further recovery may be expected as fellings recover from a position well below the level of increment (Table 2; Figure 1). There is certainly scope for growth with Romania now an EU member with predictions of an annual rise in logging by as much as $2.6 \%$ and sawnwood by $2.8 \%$. Greater rises are predicted by FAO for wood-based panels (6.3\%) and paper (5.9\%) against estimated growth in consumption of $7.8 \%$ and $6.6 \%$ respectively (Figures $2-3$ ). However in the case of newspaper the graph for future production shows an upward trajectory but one that falls further behind the consumption level. This is due to the fact that some Romanian newspapers are owned by international groups using external sources (Baltic States or China) often on the grounds of cost. 
Table 1: Wood products 1985-2004

Tabela 1: Proizvodi od drveta 1985-2004.

\begin{tabular}{|l|l|l|l|l|l|l|l|l|}
\hline \multirow{2}{*}{ Year } & \multicolumn{6}{l|}{ Product: } \\
\cline { 2 - 9 } & A & B & C & D & E & F & G & H \\
\hline 1985 & 4638 & 618 & 244 & 230 & 93 & n.a. & 493 & 81 \\
\hline 1986 & 4263 & 671 & 269 & 219 & 91 & n.a. & 504 & 86 \\
\hline 1987 & 4227 & 660 & 276 & 208 & 91 & n.a. & 485 & 73 \\
\hline 1988 & 3891 & 627 & 254 & 194 & 91 & n.a. & 505 & 75 \\
\hline 1989 & 3784 & 607 & 266 & 181 & 88 & n.a. & 485 & 70 \\
\hline 1990 & 2932 & 473 & 125 & 123 & 73 & 380 & 427 & 67 \\
\hline 1991 & 2443 & 345 & 109 & 104 & 64 & 235 & 307 & 57 \\
\hline 1992 & 2094 & 275 & 117 & 100 & 45 & 171 & 262 & 52 \\
\hline 1993 & 1916 & 20.5 & 102 & 88 & 41 & 159 & 248 & 56 \\
\hline 1994 & 1852 & 15.9 & 102 & 84 & 39 & 163 & 262 & 56 \\
\hline 1995 & 1636 & 16.6 & 103 & 90 & 37 & 235 & 332 & 47 \\
\hline 1996 & 1767 & 18.0 & 81 & 93 & 37 & 203 & 299 & 31 \\
\hline 1997 & 1738 & 15.3 & 74 & 91 & 33 & 197 & 306 & 42 \\
\hline 1998 & 1618 & 11.6 & 46 & 75 & 24 & 162 & 281 & 44 \\
\hline 1999 & 1449 & 9.9 & 51 & 67 & 22 & 178 & 276 & 39 \\
\hline 2000 & 1405 & 8.3 & 86 & 74 & 19 & 232 & 328 & 53 \\
\hline 2001 & 2530 & $10 / 3$ & 206 & 87 & 27 & 215 & 388 & 57 \\
\hline 2002 & 2706 & 6.6 & 238 & 90 & 32 & 243 & 421 & 43 \\
\hline 2003 & 2568 & 10.6 & 216 & 98 & 30 & 260 & 457 & 43 \\
\hline 2004 & 2987 & 14.4 & 280 & 117 & 31 & 237 & 492 & 42 \\
\hline
\end{tabular}

A Sawn timber th.sq.m; B Chipboard th.t (mln.sq.m from 1993); C Fibreboard th.t; D Plywood th.sq.m; E Aesthetic Veneer Sheets th.sq.m; F Pulp and semi-pulp th.t; G Paper th.t; H Paper for newsprint th.t; Source: Romanian Statistical Yearbooks

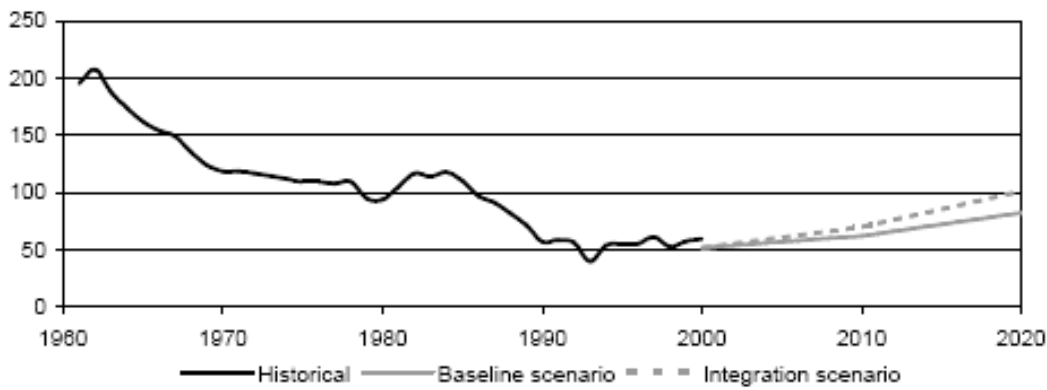

* Integration scenario relates to EU accession

Source: FAO Country Tables (European Forest Sector Outlook Study

Figure 1: Ratio of fellings to increment (percent) Slika 1: Omjer sječe drveta s ciljem porasta (procenta) 
PRIVATISATION wood harvesting, transport and processing started in early 1990, when this sector was characterised by a small number of large SOEs, some of them with a complex structure including the total integration of logging, transport and processing. Restructuring evolved in parallel with the establishment of new private companies: mainly SMEs (PARNUTA \& MACHEDON 2000). In 2001 private companies accounted for some $96 \%$ of the total production, compared with only $32 \%$ for industry as a whole. From a total of 7,038 companies, 7,018 were privately owned, and the other 20 state companies are being gradually disposed of. Privatisation has therefore taken more than 10 years to approach completion because, although beneficial for those able to overcome the competition with moderate bids for under-priced assets, ambivalence in government circles kept most logging and wood processing assets in state hands until the increasing financial liabilities became unsustainable in the face of IMF and World Bank pressure from 1997. However, given the lack of investment in the 1980s and the declining importance of traditional markets in the Confederation of Independent States (CIS) and Middle East many state assets were not immediately saleable. More than half of the employees of 1989 have been declared redundant, although for some there may be scope for re-employment in new factories referred to below. However, while privatisation produced a fragmented pattern of ownership, it also provided a good basis for consolidation by the more successful companies of the first round. Meanwhile, a Forest Sector Business Information Centre provided help to accelerate the private development of forest industries (initially involving a large number of small private sawmills often linked with woodland restitution) but the familiar problems of loan-raising occurred, arising in part from a lack of awareness of the opportunities provided by existing credit and investment partnership schemes.

Trade Control was initially in force to safeguard the home market. But the trade was liberalised at the beginning of 1998 and in terms of the balance of imports and exports the industry is clearly in surplus (despite significant import dependence for furniture - $30 \%$ of domestic consumption - paper and board). Exports of wood products were worth $\$ 410$ $\mathrm{mln}$ in 2000 (excluding furniture) and a further net export value of $\$ 625 \mathrm{mln}$ for furniture in 2002 (a total $\$ 785 \mathrm{mln}$ minus the value of imports). However Romania faces a declining market share through competition from the Czech Republic and Poland - also from the Far East (China and Southast Asia) at the cheap end. There is a need for greater efficiency in the face of rising timber and energy costs; also better training and improvements in design and marketing. The export of logs was banned during 1990-8 (and again briefly in 2001-2) in order to promote value added - though it stimulated inefficient processors because the raw material was under-valued and hence the income of the National Forest Administration (NFA) was reduced. Removal of the ban brought an increase in standing wood prices (up 50\% during 1995-2002) and increased foreign investment in wood processing, though many harvesting companies still operate at low standards. The NFA determines the level of felling each year: thus in $200117.0 \mathrm{mln} . \mathrm{cu} . \mathrm{m}$ of wood were available for harvesting: 15.3 from state forests; 1.3 from private woodlands and 0.4 from other sources. $3.3 \mathrm{mln}$.cu.m were earmarked for use by NFA and for 
heating and construction by country people, while the rest was available for processing. In $200240 \%$ of the annual cut was sold under long-term contracts and since 2001 a competition office has supervised reserve prices for standing wood sold by auction in order to safeguard Romsilva's income where competition is low. The trend in cutting is outlined in Figure 1 and Table 2.

Table 2: Important forest sector parameters 1961-2000

Tabela 2: Značajni parametri u sektoru šumarstva 1961-2000.

\begin{tabular}{|c|c|c|c|c|c|c|}
\hline \multirow{3}{*}{ Parameter } & \multirow{3}{*}{$\begin{array}{l}\text { Units } \\
\text { (millions) }\end{array}$} & \multicolumn{5}{|c|}{ Historical statistics } \\
\hline & & \multicolumn{5}{|c|}{ Year } \\
\hline & & 1961 & 1970 & 1980 & 1990 & 2000 \\
\hline \multicolumn{7}{|l|}{$\begin{array}{l}\text { Forest } \\
\text { resources }\end{array}$} \\
\hline Forest area & Hectares & 5.20 & 5.90 & 5.86 & 5.41 & 6.68 \\
\hline $\begin{array}{l}\text { Growing } \\
\text { stock }\end{array}$ & Cu.m o.b. & 938.00 & $1,268.00$ & $1,268.00$ & $1,202.00$ & $1,202.00$ \\
\hline Increment & Cu.m o.b. & 14.45 & 26.90 & 26.90 & 31.60 & 31.60 \\
\hline Fellings & Cu.m o.b. & 28.21 & 31.84 & 25.24 & 18.01 & 18.78 \\
\hline
\end{tabular}

o.b. = over bark

Source: FAO Country Tables (European Forest Sector Outlook Study)

Competition for Timber. The new logging companies have to bid for standing timber at auctions which have been held annually since 1995 ; though they only cover $85-90 \%$ of what is available, because some of the sites are not financial attractive when only thinnings are available (in which case the unthinned stands may become vulnerable to wind-blow and stem quality is affected) or the trees lie on steep slopes at a distance from the main roads with skyline cable cranes lacking. Auction prices were kept relatively low initially but since 2001 a competition office has supervised reserve prices in order to safeguard NFA's income where competition is low, while the authority decided to increase the upset price for tenders by $60 \%$ in 2005 . To try and avoid undue protection, the 1996 Forest Code did not allow long-term contracts with processors guaranteeing supply. But uncertainty was found to discourage investment and 10-year deals were permitted from 2002 in respect of $40 \%$ of the annual cut (while private forest owner associations that have established their own SMEs for logging). Again, to protect the state's revenue logging companies have to be debt-free in order to bid, but while one Vrancea forest chief was dismissed for 'robbery' arising from tender irregularities with bidding allowed by companies in debt, the near-bankrupt state-owned Brafor (Braşov) was still tolerated because it was one of the few companies with long distance skylines capable of extracting timber from relatively inaccessible areas. Only with EU accession looming was Brafor declared bankrupt (in 2005) and its assets put up for sale: the company had earlier been forced to close the Comandău sawmill (some $60 \mathrm{kms}$ northeast of Braşov) and its narrow-gauge rail link with Covasna via the inclined plane at head of Valea Zânelor and the bankruptcy formalities now complicate the conservation project 
that had started on this unique transport system which operated with the same basic technology for more than a century.

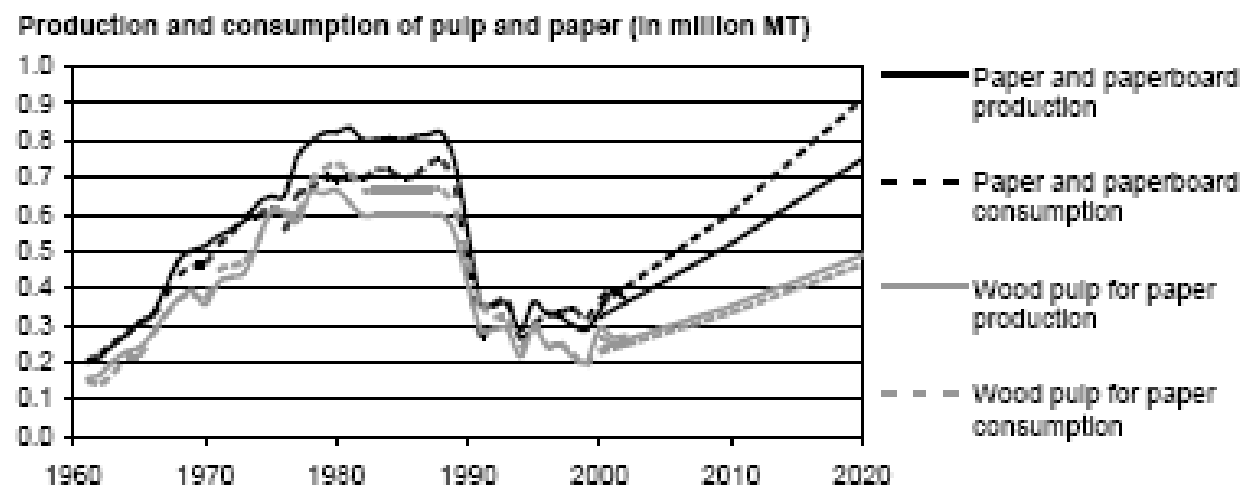

Production and consumption of solld wood products (In mIllion $\mathrm{m}^{3}$ )

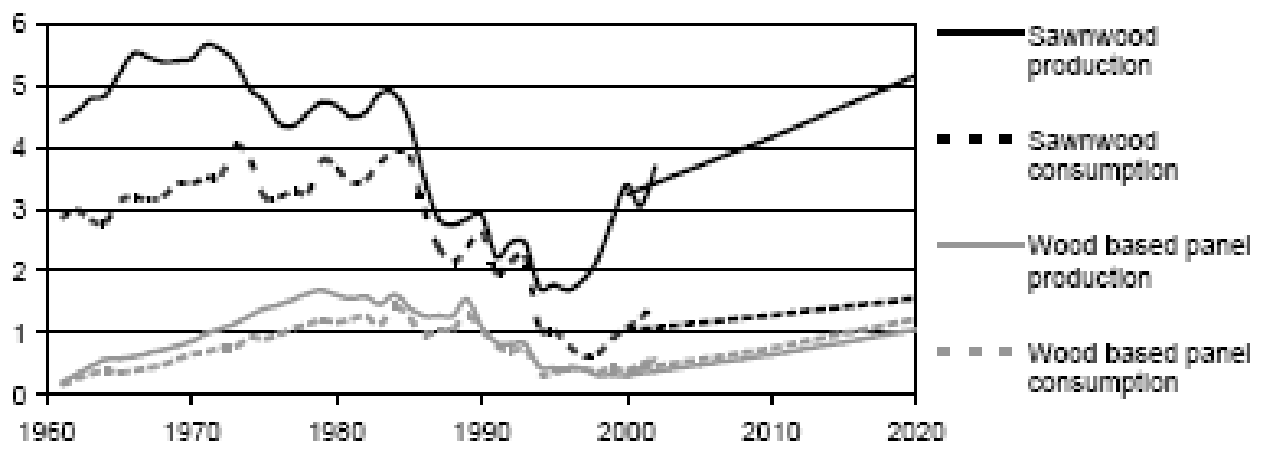

Source: FAO Country Tables (European Forest Sector Outlook Study)

Figure 2: Production and consumption of pulp and paper (mln.t)

Slika 2: Proizvodnja i potrošnja drvne kaše i papira (mln.t)

FIRST PROCESSING. Sawmilling, using softwood increasingly (with its share of all wood processing rising from $46 \%$ in 1989 to $49 \%$ in 2002 , though it did reach as much as $54 \%$ in 2000 ), is in the hands of companies who also carry out the logging operations - as was common for the exploitation and transport units of the communist period, Indeed, some also consume a proportion of their output in slow-burning charcoal kilns (some large enough to require a stack of 300cu.m - a record claimed by Lupeni in 2001). But the larger sawmills tend to constitute separate companies and look to specialist logging companies to supply them. However, a problem arises through high exploitation costs in remote areas with few roads: indeed in 1997 private wood processors believed that NFA was holding on to high quality timber in accessible places (i.e. with low exploitation expenses) for preferred customers and advocated open timber sales in the interest of transparency. Nevertheless, efficiency and technology remain low. 
Foreign direct investment (FDI) has involved some large projects from 1997 onwards: (accounting for $\$ 920 \mathrm{mln}$ out of a total of $\$ 1,526 \mathrm{mln}$ during 1990-2002) and typically they comprise complex operations in which sawmilling is only the first stage. The outstanding example is the sawmill (of $80,000 \mathrm{cu} . \mathrm{m} / \mathrm{yr}$ capacity) opened in Sebes by Holzindustrie Schweighofer (Austria) in 2004 when the company was awarded the accolade of Romania's 'investor of the year' thanks to its $€ 64 \mathrm{mln}$ greenfield project on a 27 ha site generating 1,500 jobs directly and indirectly. Romania was chosen due to low production costs and quality raw materials with the Kronospan boardmill available alongside to recycle wood chips. The company supplies quality products to the building sector with exports to 70 countries (especially Japan and the Far East) through distribution networks that will indirectly create 1,500 jobs. This follows a $\$ 300 \mathrm{mln}$ investment in wood processing at Buchin, Caransebeş by US Tenneco Packaging completed in 1998. And Egger (Austria) also set up a 90ha site outside Constanța in 2000 for the production of wooden semi-manufactured goods. At the other end of the scale the pencil factory in Sibiu continues the work of an enterprise established in 1930 (when Californian cedarwood was used), nationalised as Republica after 1948 and privatised as Euro Pencils in 1999 with a significant export business. Meanwhile the Prolemn (Reghin) door factory incorporated modern wood-processing technology thanks to $\$ 700 \mathrm{mln}$ of Turkish capital (2002): this being one four units into which the old state processing complex was reorganised. The Arad logging and transport company enterprise (IFET) was bought by Spanish investor Carlos Torija Diaz who maintained the old profile for his 'Tarima Toledo' venture. Arad products were promoted in Europe (especially Spain) following a \$2.0mln refurbishment in 1999 .

Innovations: Chain of Custody. There is still a need for greater efficiency in processing domestic hardwoods including better use of residues; also new technology for processing small diameter roundwood and improvements in yield, quality and tool life by debarking in sawmills and more sophisticated processing. Also documentation to record the 'chain of custody' in roundwood processing linked with Forestry Stewardship Council (FSC) certification of individual forests. Since 2000 more than 50 foreign companies (mainly West European) and several Romanian companies have expressed their interest in buying FSC-certified broadleaved and coniferous timber and timber products. The first certificated forests $(31,600 \mathrm{ha})$ were established in 2002 and it is expected that the number of certified companies operating in Romania will grow rapidly. At present certification covers a limited range of products (including roundwood, raw and coated medium-density fibreboard (MDF), kiln-dried and profiled wooden elements of various species, garden furniture and joinery products) but it is expected that their number will increase significantly in the near future. Meanwhile a quarter of the domestic demand for primary processed timber was imported, especially aesthetic veneers and plywood in the mid-1990s. 
BOARDS, PLYWOOD AND VENEERS. This section takes the study into the realm of reconstituted wood products that involve an early generation comprising plywood, boards: both medium-density fibreboard (MDF) and particleboard or chipboard (PAL according to the Romanian acronym). The theory is that bonding strands, veneers and other forms of wood fibre can yield larger composite units stronger and stiffer than the sum of the parts. At the same time waste is reduced and better use can be made of lessexpensive fast-growing timber. Due to poor quality and outdated technologies, the particleboard, veneer and plywood sectors declined greatly from a quarter of all wood processing in 1989 to just eight percent in 2002. However, as nored above, MDF production has recovered as a result of foreign investments, with $83 \%$ of production for export, and other investments should allow plywood and chipboard sectors to recover as well. Romanian firms include Mopaf Vrancea (Focşani) which produces fibreboard from waste generated by the company's adjacent furniture business and it is the only producer apart from Kronospan (already referred to). In addition to the domestic market the company exports to France (Parisot), Germany (Müller) and Italy (Santa Rossa); it would also like to resume exports to the CIS. Modern technology was also installed during 1995-6 at the Inprelg (Gugeşti) plywood factory with 15,000cu.m/yr capacity of which $80 \%$ is exported. As regards the foreign investments, Gruppo Frati (Italy) opened its MDF plant at Sebeş plant in 2000 with an annual capacity of 290,000cu.m (8001,000 cu.m/day); followed in 2001 by its PAL factory in the same town (hence 'Sepal') combining a modified form of particleboard $(900,000 \mathrm{cu} . \mathrm{m} / \mathrm{yr})$ with melamine laminated board (5.0mln.sq.m/yr) and plywood. A factor in the Sebeş location was the availability of 'mountains of sawdust' dumped along the Arieş and Ampoi rivers by small peasant sawmillers in the Apuseni Mountains. However Frati have now sold their mills to Kronospan (Austria) who are supposed to have encountered PR problems with ureaformaldehyde glues produced in Sebeş.

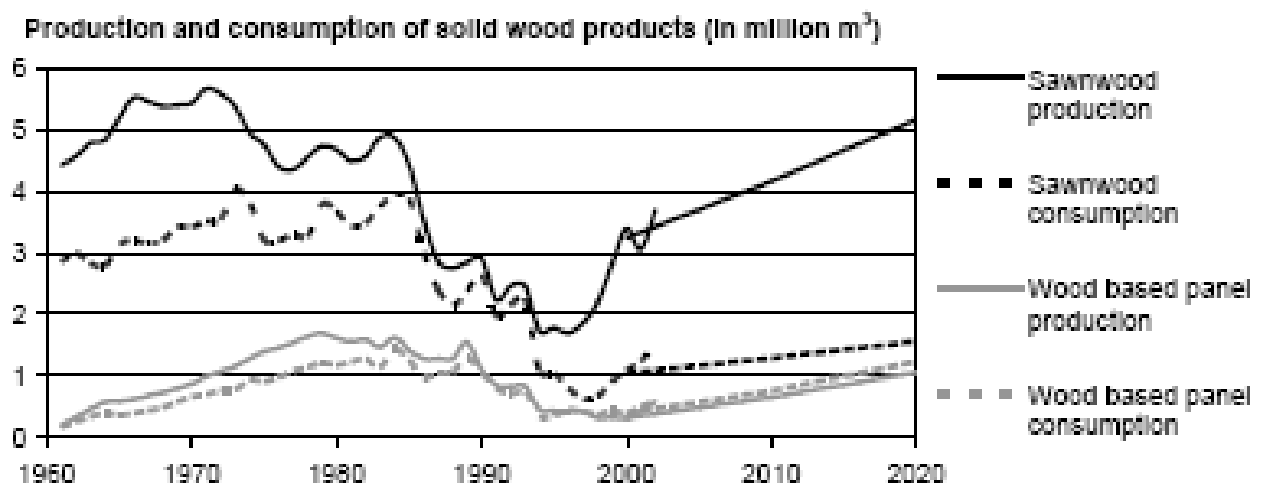

Source: FAO Country Tables (European Forest Sector Outlook Study)

Figure 3: Production and consumption of solid wood products (mln.cu.m) Slika 3: Proizvodnja i potrošnja proizvoda od čvrstog drveta (mln.cu.m) 
Finnforest (part of Finland's Mersaliitto Group) invested in upgrading MDF production in 2003 at their Bacău-Comăneşti (BACO) factory in Moldavia: an enlargement of part of the old state wood-processing complex (with its 6,000 employees) initially restructured as Comprel until Finnforest took over in 1999. Rehabilitation then took place using Austrian, German and Italian machinery including presses to fabricate furniture 'plates' exported to Europe, North American, Japan and some Asian countries. Wood panels are also coated with a decorative veneer of cherry, maple, oak and other timbers for export. The company has maintained the former state company's interest in combining spruce with fast-growing tree species e.g. poplar and birch from the Brăila 'great island' (within the Danube) although this area is located $200 \mathrm{kms}$ from the mill. This project, like other foreign investments, Such involves 'state of the art' technology to make the best use of the raw material, with additional benefits through lower energy use, lower pollution (carbon dioxide and other emissions). Waste is burnt in 5MW power station. Meanwhile in Braşov Kronno Gruppe (Switzerland) have opened a factory for MDF, PAL, decorative paper and laminated wood as well as doors and window, while RG Holz (Switzerland) have opened a new unit at the old state sawmill of Vişeu de Sus in Maramureş (employing 1,050 workers) to bind off-cuts within covers of water-resistant MDF (known as 'tocatura') to manufacture doors and windows. Retooled using German, Italian and British equipment (with $80 \%$ exported): the mill processes $20,000 \mathrm{cu} . \mathrm{m} / \mathrm{month}$ for planks ('cherestea') and reconstituted timber products; retaining the local forest railway for transport for environmental reasons.

Other Foreign Investments. Losán (Spain) invested in a 35mln.sq.m/yr veneer factory in Braşov during 2001-2, consuming 35,000cu.m of timber; while Werzalit of the Constantia Group (Germany) opened a veneer factory at Lugoj, entirely for export, consuming 25,000cu.m/yr of timber. Bloemberger Holzindustrie (Germany) invested in a $12,000 \mathrm{cu} . \mathrm{m} / \mathrm{yr}$ plywood plant of starting in 2001 and a veneer plant of similar capacity starting in 2003 on the premises of the world's oldest beech plywood producer: Cildro at Drobeta-Turnu Severin. This follows the takeover of the former state complex in 1998 and its 2,200 workers, followed by a record export rate of $95 \%$ in 2001 with improved 'phenolic film-faced plywood' that is water-resistant and mechanically-resistant plywood for lorry/industrial floors and industrial furniture (including moulds for the aircraft industry) as a result of German management and re-engineering during 1998-9. Productivity has increased and veneer production has grown to $20 \mathrm{mln} . \mathrm{sq} . \mathrm{m} / \mathrm{yr}$ making the plant the largest veneer producer in the region in 2001. The factory's traditional emphasis on furniture is being reduced in favour of aesthetic veneers and plywood for the German market (facilitated by new equipment from the German investor). Egger and Holz (Austria) are now (2006) investing €210 $\mathrm{mln}$ in factories in Suceava country to work up both local and imported waste with the aim of generating 1,100 jobs (plus 4,000 indirectly). The project is being launched in partnership with the European Bank for Regional Development (EBRD) and could be worth $€ 500 \mathrm{mln}$ eventually. Several Romanian factories are producing furniture boards that involve advanced processes e.g. Alprom (Piteşti), Mopel (Bistriţa), Pamof (Curtea de Argeş), Rostrumo (Târgu Jiu), 
Sigstrat (Sighetul Marmației) and Stratusmob (Blaj); while Energy Impex (Cluj) has Italian capital.

Engineered Wood Products (EWPs) lie at the root of much of this activity. They constitute a new generation of structural products making much more efficient use of the timber resource. Their success is a response to a global shortage of good timber that first became evident in the USA when growing demand for quality structural wood products could not easily be satisfied through traditional solid-sawn processing since logs were becoming smaller in diameter and poorer in quality: plywood producers were particularly badly affected. EWPs now reduce reliance on sawn timber while creating wood-based products that compete with alternative materials over a greater range of dimensions than was initially thought possible. They have more uniform properties than solid wood alternatives, as well as higher design strengths, and they are less liable to deform in service. They can utilise varying species, qualities and sizes of raw material; for the raw material is reduced in size before reconstitution with adhesive to form a beam or panel capable of carrying a structural load. The principle can be extended to include products that combine different types of wood-based elements, or combine wood-based products with reinforcing element of other materials. As with solid wood, when EWPs are used in a fire rated construction system, they have predictable performance that allows a building to be evacuated safely. The most familiar EWPs are also the oldest: glued laminated timber (glulam) and plywood are over 100 years old. Both these products extend the use of wood to dimensions not possible with sawn timber, but they still use relatively large pieces of the raw material: glulam is made of planed timber lamellae, about $35 \mathrm{~mm}$ thick, while plywood uses large sheets of veneer.

More recent developments use much smaller components; beginning with panels using 'flakes' or wafers, such as oriented strand board (OSB) - otherwise known as flakeboard or Tischlerpatten) - that developed rapidly in the 1970s: resin binders join the flakes under great heat and pressure, with the exterior layers oriented in the long panel direction while the interior layers are aligned crosswise or randomly. The product combines strength and rigidity with lightness, moisture resistance, uniform quality and effective use of wood while eliminating knots and knot holes. Goods with similar cross-sections to solid wood have also been developed using veneer sheets, veneer strands or flakes: such structural composite lumber (SCL) involves a continuous processes and length is limited to some $20 \mathrm{~m}$ only by the practicalities of transporting the product. There are different types if SCL. Laminated veneer lumber (LVL), which has its roots in the aircraft industry of World War Two, is composed of sheets of veneer laid parallel to form a panel (usually c. $70 \mathrm{~mm}$ thick) sawn to the required width to make beams for long spans. Parallel strand lumber (PSL), introduced in the mid-1980s as a replacement for large section solid wood components, is made of veneer clippings (included some low quality material) bonded in a microwave press to form beams of up to $280 \times 482 \mathrm{~mm}$ cross-section. Laminated strand lumber (LSL) - also called oriented strand lumber (OSL) - was launched in the early 1990s to convert debarked logs directly to strands of up to $300 \mathrm{~mm}$ length. The adhesivecoated strands are pressed with steam injection to form panels up to $140 \mathrm{~mm}$ thick, $1.2 \mathrm{~m}$ 
wide and $14.6 \mathrm{~m}$ long. However, the most popular product that combines different types of SCLs is the wooden I-joist (widely used for stable lightweight floors in timber structures) which has an OSB web and LVL flanges.

Apart from glulam, EWPs are usually invisible in the finished building, since they are surrounded by insulation and clad with some type of sheathing. However, their popularity is increasing since they have high performance, light weight, ready availability and are easily worked without specialist tools. They can be found in single and multi occupancy housing, housing, industrial and agricultural sheds, superstores and schools. The use of glulam in sports halls and arenas is particularly well-established. However some of these advanced products are not yet made in Romania and although the Fordaq directory (see:www. fordaq.com) links 51 Romanian companies with OSB it seems that they are selling this material rather than producing it (although foreign companies are often interested in exporting constituent elements such as boards and veneers). It is obviously that Romania should become more involved with EWPs in general. The Comprel the Sepal factories may extend into OSB (Kronospan who own the latter are currently producing it at their factories in Burgas in Bulgaria and Jihlava in the Czech Republic) while other possibilities are Egger at Botoşani and Kronno Gruppe in Braşov. Meanwhile, increasing amounts of OSB are being used in construction $(50,000 \mathrm{cu} . \mathrm{m}$ in 2006 compared with 33,000 in 2005) which will mean more imports if domestic capacities are not increased (UNECE 2006).

PAPER-PULP-CELLULOSE. Pulp and paper account for only $12 \%$ of all wood processing compared with $18 \%$ in 1989 . Although there has been no major change in capacity the product range has widened with a sharp growth in technical paper production and in duplex-triplex packaging materials during 2001-2, while newsprint paper production decreased by $33 \%$. Romania operates a network of units of the $\mathrm{CCH}$ type: 'Combinat de Celuloza şi Hârție' i.e. cellulose and paper combines - including Ambio (Suceava), Cahiro (Scăeni), Celhart (Brăila), Celohart (Zărneşti), Celrom (Turnu Severin), Comceh (Călăraşi), Hârția (Buşteni), Hicart (Prundul Bârgăului), Letea (Bacău), Molidu (Vama), Palas (Constanța), Pehart (Petreşti), Petrocart (Piatra Neamț) and Someş (Dej) and Vrancart (Adjud). Some are long-established like the Pehart plant started in 1854 at a water power site south of Sebeş and rebuilt after a fire during 1856-8, Someş opened in 1863, while Hârția was built by the Schiel Brothers in 1882 and Celohart originated as separate but adjacent paper and cellulose industries dating to 1857 and 1893 respectively. Some highly-placed individuals were involved: the Letea (Bacău) paper factory was set up in 1881 on the recommendation of the then-prime minister Ion Brătianu. However cellulose production collapsed to 222,000t 1998 compared with $658,000 \mathrm{t}$ 1989, while paper and cardboard production was down to 324,000 from 710,000 . This trend was due to a reduction in domestic consumption (aggravated by VAT as well as high energy and raw material costs) plus a preference for expensive imported papers attracting only low duties on account of CEFTA and EU accords: 15\% in 1998 but now nil for CEFTA and only nine percent for EU (prior to accession) and Turkey. However, although only Celhart and Celrom were privatised by 1999, most of the others 
followed soon after (e.g. 'Hârția' by the Omnimpex Group in 2000) while the Piatra Neamț factory was liquidated.

Restructuring Scenarios. With 1,100 employees, Someş was once responsible for $90 \%$ of Romanian natural paper exports and $57 \%$ white paper exports, but made heavy losses in the 1990s. With only $60 \%$ of the domestic market secured - plus low prices and competitiveness on foreign markets - upgrading was discouraged and some capacities were moth-balled. However, when Hovis (Austria) who bought the SOF stake in the factory were only interested in the tissue and toilet paper factory, white paper and cellulose. They gave up production of cardboard and other types of paper and disposed of the surplus plant to All Metal (Belgium) for scrap recovery. The plant has now been acquired by Romanian Commercial Services in 2004. Meanwhile a packaging and paper plant of 150,000t/yr was started by Group Rosman (France) at Ambro in 2000, with $\$ 18 \mathrm{mln}$ (out of a total investment of $\$ 68 \mathrm{mln}$ ) was obtained from EBRD and IFC to modernise the pulp and paper mill initially acquired by the French Sical packaging group in 1996 during the first wave of privatisation. The project has increased efficiency and doubled capacity to meet home demand for kraft paper and sacks and develop exports, while improving environmental conditions.

Other examples show a balance between Romanian and foreign companies. Vrancart, which started in 1983, with paper machines installed during 1983-6, has had its pulping system modernised by its Romanian owners using Italian and Swiss machines (19952002) with emphasis on corrugated cardboard and toilet paper; securing a big increase in labour productivity. Meanwhile, Celohart Zărneşti was bought by Ecopaper (also a Romanian company) who retained the cardboard factory only and closed the cellulose section in 2001. Ecopaper use 35\% of Romania's waste paper to supply corrugated paper to Ecopack (who in 1997 acquired the Ghimbav cardboard factory - established in 1921 and converted it for packaging) and other companies in Romania and abroad. On the other hand in 2003 Perrini (Italy) started a new 30,000t/yr tissue paper plant using deinked waste paper at the Conceh (Călăraşi) plant first opened in 1964: 430 workers now make toilet papers, kitchen rolls, napkins and handkerchiefs using recycled paper and cellulose. Some lost markets have been regained with a tendency to widen the product range with more emphasis on technical paper production and packaging materials and less emphasis on newsprint. Meanwhile, some entirely new factories have opened: Dunapak, part of Hamburger (Austria), invested $\$ 15 \mathrm{mln}$ in a modern corrugated cardboard factory at Sf.Gheorghe during 1996-7: aiming at production of 60mln.sq.m/yr to secure 180-200 jobs; while the Lumex - a Romanian-Italian joint venture cardboard factory - opened at Sântana near Arad in the same year.

Letea (Bacău) is a complex case involving recycled newsprint and toilet paper, with problems of high power consumption (hence debts to the electricity supplier) and high raw material costs in the context of free import of newsprint. After 1990 the factory production started to decline and, despite government subventions, it was reported closed in 1997: part of a pattern of heavy job losses in the cellulose and paper sector. Since even 
more newspaper had to be imported as a result, there were plans launched in 1996 for a modern plant for processing 50,000t/yr of waste paper (yielding 40,000t paste for manufacturing process) to avoid problems of raw material supply in winter, reduce wood consumption, create 130 new jobs and service export orders which currently were not being fulfilled. But although $90 \%$ complete, the project remained on hold after 1996 with no funding available for completion. In 1998 the State Ownership Fund (SOF) adopted a potentially profitable restructuring strategy with labour cut from 2,640 to 1,500 and newsprint production resumed at Letea as the sole national producer. However this initiative was undermined by a wood supply crisis in 1998 (blamed on the liberalisation of exports that surged ahead in 1998 to the detriment of domestic consumers) that prevented continuous working. In 1999 privatisation was contemplated by four companies - the Magnat Impex domestic company, Saba Investments (Cyprus) and two Turkish companies (Altum Maya Sanaya and Ovalar) - in direct negotiation with SOF. Although it was reported that Sama paid $\$ 11 \mathrm{mln}$ in 2003 for a majority stake in a venture involving a 40,000t/yr newsprint plant using de-inked waste paper, this deal evidently fell through and the Romanian company Selana, associated with D.Sechelariu and D.Umbrărescu (two local capitalists close to the then ruling Party of Social Democracy), although some shares were reportedly ceded to four other potential buyers in 2005 in a bid to boost product quality. However, since November 2006 Selena Bacău has increased its holding to $98.5 \%$ following a $€ 6 \mathrm{mln}$ investment programme with production of $100,000 \mathrm{t}$ of newsprint anticipated in the near future. Without the investment, which was a condition of the privatisation, that state could have reclaimed the factory. Indeed the long period of uncertainty over the future of this factory is one reason why the output of newspaper remains below the level of domestic consumption.

FURNITURE. Furniture was the first to emerge from the restructuring and modernisation process necessary to penetrate new markets. There has been steady growth occurred from 1994 and the 1990 level was passed in 1998. Compared with 497 units in 1990 there are now about 2,100 factories and workshops (some estimates go as high as 2,680), employing around 95,000 (almost five percent of the total workforce in industry) with only a handful retaining majority state-ownership. The production of furniture is structured as follows: $27.7 \%$ for bedrooms and dining rooms; $27 \%$ small furniture and chairs; $11.4 \%$ corner units and book cases; $10 \%$ upholstered furniture and $9 \%$ kitchen furniture. More than half is made out of beech compared with $20 \%$ for oak and $15 \%$ for coniferous species. Units have tended to adopt integrated systems i.e. without cooperation with other factories or units producing prefabricates and components. The industry has adapted well to the westward market orientation from the east (which had once taking $35 \%$ of exports), but problems have arisen through lower timber cutting levels since 1989 and a lack of integration with board/panel producers export much of their output in 2003. Once again the freeing of timber exports has increased the price of wood; thus making furniture more expensive at a time when domestic spending power is low. 
The Administration Board of the Association of Furniture Producers of Romania (AFPR, set up in 1992) considers that falling production has pushed a range of exporters to the verge of liquidation: Armob (Bucharest), Confolux (Sf.Gheorghe), Medimob (Mediaş), Ozanamobex (Târgu Neamț) and Sigmob (Sighet) in 1999. It is also regrettable that while there is strong demand for Romanian furniture abroad (on the grounds of strength and price) Romanian firms often insist on office furniture imported from Italy. However, in 2002 the industry had a production value of at least $\$ 785 \mathrm{mln}$ of which $\$ 624.6 \mathrm{mln}$ represented export revenues - five percent of the country's total exports (a positive balance of $\$ 519.3 \mathrm{mln}$ after allowing for imports of $\$ 105.3 \mathrm{mln}$ ). The main markets were in Germany $(\$ 132 \mathrm{mln})$, France $(\$ 117 \mathrm{mln})$, The Netherlands $(\$ 72 \mathrm{mln})$, Italy $(\$ 69 \mathrm{mln})$ and Austria (\$52mln). Furniture then accounted for 39\% of all wood processing, but with an export level of $65 \%-75 \%$ it accounted for $45 \%$ of total branch exports - earning strongly in national currency with appreciation of the Euro - compared with $26 \%$ in 1989 . This performance should be maintained so that furniture may achieve a share of $42 \%$ of all wood processing by 2010 .

The Future is Problematic with struggling debt-ridden companies facing the prospect of stiffer competition from other transition states and from China and Southeast Asia. The industry has many strengths with $90 \%$ of the raw materials provided domestically and a highly-trained workforce. A study by the Ministry of Industry \& Commerce and Phare in 1998 highlighted high capacity and growth potential as factories obtain funds from EU or SOF sources to assimilate new finishing technologies and increase value added. But cheap labour is often 'wasted' by low productivity $(\$ 5,000$ output per worker in Romania but $\$ 78,000$ in Western Europe) and it is estimated that an investment of $\$ 1.0 \mathrm{bln}$ is needed to upgrade technology and secure a more competitive position in world markets. Better quality control is needed through ISO 9000 with SWOT analysis to gain commercial efficiency (concentrating on the profitable enterprises and slimming down to reduce space). More efficient heating and machinery is needed to reduce power consumption (also improved filtering, and ventilation in summer). Tradition must evolve through aesthetic design; gearing up to a more flexible approach towards western markets through subcontracting for cheaper components and accepting smaller orders than might be desired. AFPR think that more use could be made of international trade fairs, joint ventures and Western shareholdings; also foreign banks and international audit companies as 'antenna for foreign investors'. Furniture producers could also buy sawmills and even forest concessions to reduce raw material costs. AFPR has joined the European Union of Furniture Producers and the National Union of French Furniture Industries in a project of industrial and business cooperation to study the profile of the Romanian sector, provide training and a web site with a view to boosting the exports of a strategic industry further (1999). While $90 \%$ of exports go to the EU, the Russian market (worth $\$ 150 \mathrm{mln}$ annually pre-1989) could be reclaimed if high tariffs and problems in the Russian banking system could be overcome: especially the uncertainty over payment in the absence of a Romanian-Russian Bank. Some export companies for Romanian furniture to Russia are being set up and in 2001 Tehnoforestexport was negotiating the extension of a Romanian-Russian joint venture set up in 1999. 
Optimism is grounded in new SMEs with young, ambitious management and growing export orientation. They are located in all parts of the country and not necessarily in mountain areas. Names that crop up in connection with exhibitions and foreign trade initiatives Alpitex and Alprom (Piteşti), Cesimob (Cehu Silvaniei), Imar (Arad), Mobex (Târgu Mureş), Mobicrasna (Carei), Mobis (Sebeş), Moldomobila (Iaşi), Mopaf Vrancea (Focşani), Roblex (Reghin), Rommobil (Stei), Samobil (Satu Mare), Silvarom (Bucharest) and Simex (Simleu Silvaniei). Rommobil exports most of its furniture (bedrooms, bookcases, kitchens) to Czech Republic, Germany and Hungary thanks to a SOF credit for new equipment (1996); while Mopaf Vrancea produce furniture for bedrooms, living rooms (including glass cases and book cases), kitchens and offices) aiming (in 1999) at a wider product range through long-term contracts with foreign partners. Particular reference should also be made Imar established in 1890 by L.E.Lengyel who supplied the Hungarian monarch (and Austrian emperor) and later entrusted by Romania's President Ceausescu with the supply of furniture for his 'Casa Republicii' project in Bucharest during 1985-90. Now, as a private factory once again, 800 employees export $80 \%$ of their output to EU states as well as CIS, USA and Switzerland. By contrast, Simex were established only in 1996 but have quickly gained a reputation for quality furniture using beech, oak and cherrywood.

Some problem factories are managing to reopen e.g. Extramob (Târgu Lapuş) in 1999 (two years following liquidation) after four associates invested 1.6bln.lei on new equipment and technology; taking on 50 former employees and soon 150 (1999). Although potential entrepreneurs are often discouraged by 'fear of bureaucracy' from making substantial investments, a redundant mining engineer has set up a new furniture workshop in Hunedoara 'less-favoured area' (with the help of fiscal concessions) to employ 40 people working to customer orders. A larger factory will now offer positions to 200 unemployed people. There are also several cases of foreign involvement. Romanel was set up in Vatra Dornei in 1998 as a Romanian-French joint venture, while Morsa (Rậmnicu Sărat) secured a DM12mln credit, through participation by a group of German companies, for updating furniture production; and Quadra Invest (a Romanian-Dutch joint venture) generated a $€ 1.3 \mathrm{mln}$ investment for the Târgovişte furniture factory (2001); and Werzalit Lemn Tech (Germany) started producing bed slats and furniture at Lugoj in 2000. Finally, a new oak furniture factory is located at Ulmi (Târgovişte) for the European and North American market based on an association including Danish, Icelandic and Portuguese firms, the Investment Fund for Central \& Eastern Europe and two Romanian companies: Vicas (Târgovişte's Victoria chemical company - renamed in 1992 and privatised by employee-management buy-out in 1994 - produces laminates while Vascony Prod is a wood processor established 1994. Variations include insulated panels with a polyurethane core contained by OSB or plywood and 'glulam'. 
Large Furniture Sellers can help the industry, notably Ikea (Sweden). Plimob (Sighetul Marmatiei), which has taken over part of the former state wood processing complex in the town, has attracted modernisation funding in 1997 to replace equipment more than 30 years old (especially for drying, polishing and assembly) while reducing energy and raw material costs. Ikea also acquired a majority holding in Mobinech (Nehoiu) in 1999 to revive activity and introduce new technology and improve quality and productivity (with higher salaries, better social protection and holiday bonuses) to secure exports to America, Australia and Europe. And the Swedwood Group (established in 1991 as part of Ikea, with units in Bulgaria, Germany, Hungary, Latvia, Poland, Slovakia and Ukraine) has opened a wood processing and furniture factory at Siret (Suceava), close to sources of high-quality resinous timber (3,200cu.m needed monthly). The 36,000sq.m factory is situated on a marshy site (previously used as a rubbish dump) and will work up from 100 to 300 employees as three shifts are organised. Sawdust is used as an energy source (2000). Italsofa (Baia Mare), owned by Natuzzi (Italy), is to double production through a new factory announced in 2004 and Mobelfabrik (Austria) is embarking on a $€ 15 \mathrm{mln}$ 10,000sq.m sofa factory Salonta that could grow expand to employ 500 by 2015 . Meanwhile the Romanian producer Alpitex (Piteşti) has a nationwide chain of shops and the same pattern of integration is evident on a larger scale in the case of Mobexpert, started in Bucharest by Dan Şucu 1993 with shop for office furniture and a factory in Bucharest (Ergo Mex) the following year producing office chairs and (now) some melamine furniture. An expanded retail chain in 1995, selling mainly imported furniture, has been combined with production from three furniture factories acquired from SOF: Samus (Dej), now specialising on home furniture, Ilefor (Târgu Mureş) currently turning out quality wooden furniture for export; and Mobstrat (Suceava). Production continues to develop in the four centres with four including new units in Targu Mureş: (Mureş Mex) for modern home furniture that achieves European productivity levels while (Modulo Mex) produces modern PAL/melamine furniture.

\section{CONCLUSION - Zaključak}

Industrija je ostvarila značajan napredak tijekom tranzicije, s prijenosom u privatno vlasništvo, i značajne nove investicije. Međutim, u većini slučajeva proizvodnja nije vraćena na nivoe 1980-ih i daljna djelotvornost je od presudnog značaja za buduće strategije oživljavanja rasta, obzirom na rastuću konkurentnost Dalekoga istoka. Iako je jeftina radna snaga privukla strane ulagače u prethodnim godinama, rastući prihod će vjerojatno umanjiti ovu prednost sad kad je Rumunija članica EU-a i konkurentnost će dodatno opteretiti dodanu vrijednost. Ovo zahtijeva porast proizvodne efikasnosti, ali također i razvijanje dizajnerskih sadržaja i poboljšanje Rumunjskog EWPs (European Wood Products - Evropskih proizvoda od drveta). Na tim osnovama Rumunija bi se mogla pojaviti kao ključni igrač EU-a u kontekstu sadašnjeg promjenjivog trenda na tržištu drvne industrije. 


\section{REFERENCES - Literatura}

1. C.Istratescu, A.Sereny \& G.Parnuta 2001, 'Forest products annual market review 2000-2001: Romania's forest products markets', FAO Timber Bulletin 54(3), 21-32;

2. E.PARNUTA \& I.MACHEDON 2000, 'Forest and environmental legislation in Romania', Anon ed., Challenges in implementing forest and environmental legislation in European countries with economies in transition (Zurich: ETH) 69-77.

3. UNECE 2006, Timber Committee: 64th session 3-6 October 2006 http://www.unece. org/trade/timber/mis/market/market-64/market-64.htm

\section{SAŽETAK - Summary}

U vlasničkim odnosima u drvnoj industriji Rumunije, desile su se značajne promjene $u$ periodu od 1990. godine na ovamo. Došlo je do restitucije kompanija koje su nacionalizirane 1948. godine, kao i do procesa suštinske privatizacije državnih kompanija. Ovaj rad predstavlja izvještaj o procesu privatiziranja i nastoji predočiti korake koji su preduzeti u prethodnoj deceniji s ciljem stvaranja novih kapaciteta za drvnu industriju Rumunije. 